\title{
Delineating the effect of demethylating agent 5-aza-2'-deoxycytidine on human Caco-2 colonic carcinoma cells
}

\author{
XIUMEI LI, BINGZHAO QIN and BO LIU \\ Department of Gastroenterology, Xiangyang Hospital Affiliated to Hubei University of Medicine, \\ Xiangyang, Hubei 441000, P.R. China
}

Received September 30, 2015; Accepted May 6, 2016

DOI: 10.3892/ol.2016.4551

\begin{abstract}
Aberrant epigenetic changes are known to contribute to various phases of tumor development. The gene function loss caused by aberrant methylation is analogous to genetic mutations. Unlike genetic mutations, epigenetic alterations can be reversed. 5-Aza-2'-deoxycytidine (5-aza-CdR) has been approved by the Food and Drug Administration for the treatment of certain types of cancer, such as MDS and leukemia. The aim of the present study was to determine whether 5-aza-CdR has the potential to be used in the treatment of colon cancer using a human Caco- 2 colonic carcinoma cell line. The effect of 5-aza-CdR on cell proliferation, cell cycle, apoptosis and reversal of aberrant methylation of the Ras association domain family 1A (RASSF1A) gene was also examined. The 5-aza-CdR was prepared at different concentrations in sterile tri-distilled water at $0.4,1.6,6.4,25.6$ and $102.4 \mu \mathrm{mol} / 1$ and employed to treat the human Caco-2 colonic carcinoma cells. An MTT assay was used to detect the effect of 5-aza-CdR on cell proliferation. Flow cytometry was used to examine the cell cycle and apoptosis. The RASSF1A mRNA transcript level was examined by reverse transcription-polymerase chain reaction. The results showed that 5 -aza-CdR inhibited the proliferation of Caco-2 cells in a time- and concentration-dependent manner $(\mathrm{p}<0.01)$. The 5 -aza-CdR treatment affected the cell cycle and caused accumulation of cells in the G0/G1 phase and this effect was concentration-dependent $(\mathrm{p}<0.05)$. 5-aza-CdR treatment caused an increase in the number of cells undergoing apoptosis and reactivated the RASSF1A tumor suppressor gene that was silenced by hypermethylation in Caco- 2 cells. In conclusion, 5-aza-CdR inhibited growth and promoted apoptosis in Caco- 2 cells by upregulating the epigenetically silenced tumor suppressor RASSF1A gene.
\end{abstract}

Correspondence to: Bo Liu, Department of Gastroenterology, Xiangyang Hospital Affiliated to Hubei University of Medicine, 15 Jiefang Road, Xiangyang, Hubei 441000, P.R. China E-mail: 13871623508@163.com

Key words: 5-aza-2'-deoxycytidine, Caco-2, colon cancer, Ras association domain family $1 \mathrm{~A}$, aberrant methylation, demethylation

\section{Introduction}

The biological consequence of gene function loss caused by DNA methylation is analogous to the consequences of gene mutation (1). Unlike gene mutation, DNA hypermethylation can be reversed pharmacologically using DNA demethylating agents. An association between DNA methylation of tumor suppressor genes and the development of colorectal cancer has been previously reported (2-5). The re-activation of tumor suppressor genes that are silenced by DNA hypermethylation is commonly termed epigenetic therapy, which is a feasible and achievable strategy for cancer treatment. Previous in vitro experiments identified that, 5-aza-2'-deoxycytidine (5-aza-CdR) can reactivate epigenetically silenced tumor suppressor genes, thereby restoring their inherent anti-cancer effect.

The Ras association domain family $1 \mathrm{~A}$ (RASSFIA) gene is located in the short arm of chromosome 3 , originally found as a novel candidate tumor suppressor in lung cancer $(6,7)$. The aim of the present study was to examine the effect of 5-aza-CdR on proliferation, cell cycle and apoptosis in Caco-2 cells in vitro. In addition, a semi-quantitative analysis of RASSF1A transcripts was carried out to determine the reactivation of the tumor suppressive function and whether 5-aza-CdR can be extended to treat colon cancer.

\section{Materials and methods}

Cell lines and culture. Human Caco-2 colon adenocarcinoma cells, purchased from Shanghai Jiahe Biotechnology Co., Ltd., Shanghai, China, were cultured in RPMI-1640 medium supplemented with $100 \mathrm{ml} / 1$ calf serum (Wisent, Nanjing, China), $100 \mathrm{kU} / 1$ streptomycin (Wisent), and $100 \mathrm{kU} / 1$ penicillin (Wisent) at $37^{\circ} \mathrm{C}$ with $5 \% \mathrm{CO}_{2}$. Subsequently, 5 -aza-CdR (Sigma, St. Louis, MO, USA) was dissolved in tri-distilled water and stored at $70^{\circ} \mathrm{C}$. The desired concentration of 5 -aza-CdR was obtained by serial dilution of the stock solution.

Monoplast suspension was obtained by digesting the Caco-2 cells in the logarithmic phase using trypsin $(2.5 \mathrm{~g} / \mathrm{l})$. This monoplast suspension was cultured and passaged to obtain the concentration of $2 \times 10^{6} / 1$. The cell suspension was then treated with 5-aza-CdR at different concentrations of 0.4, 1.6, 6.4, 25.6 and $102.4 \mu \mathrm{mol} / \mathrm{l}$. At every $24 \mathrm{~h}$, the medium was aspirated and replaced with fresh RPMI-1640 medium containing 
$\mathbf{A}$

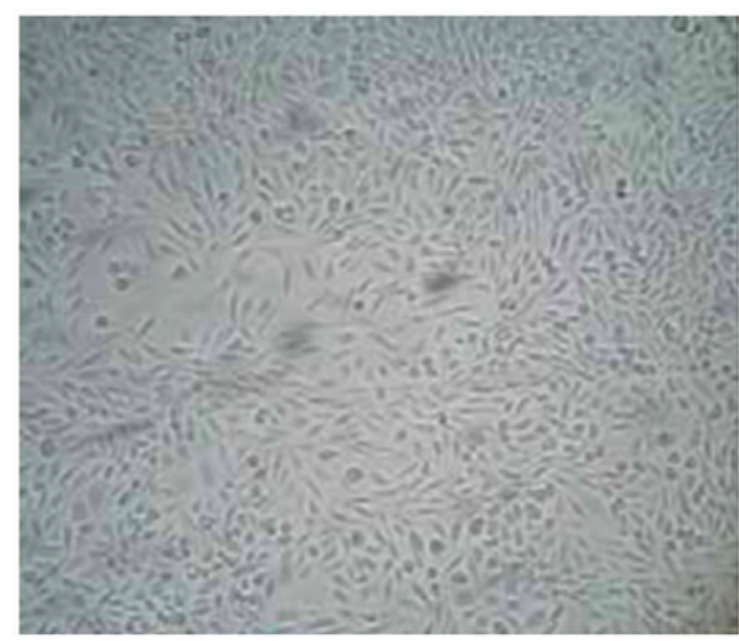

B

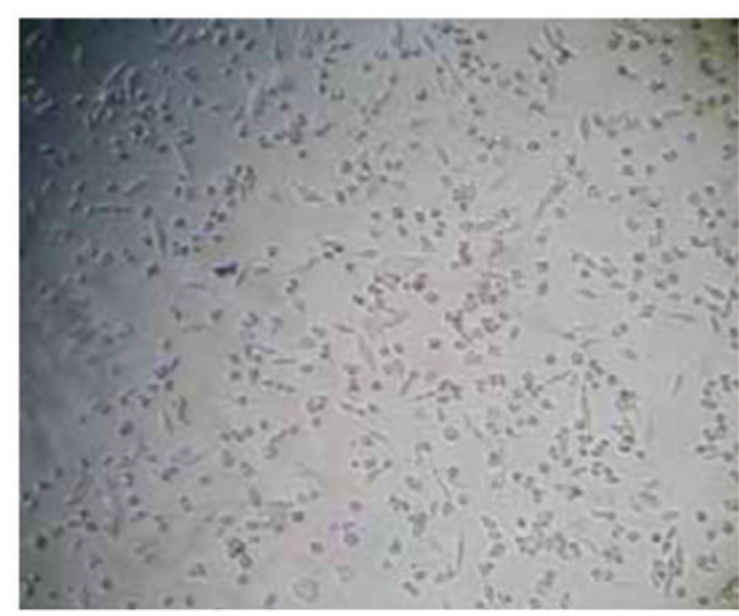

Figure 1. (A and B) Caco-2 cell morphology following treatment with $6.4 \mu \mathrm{mol} / 15$-aza-2'-deoxycytidine for 3 days. A decrease in volume and density was identified.

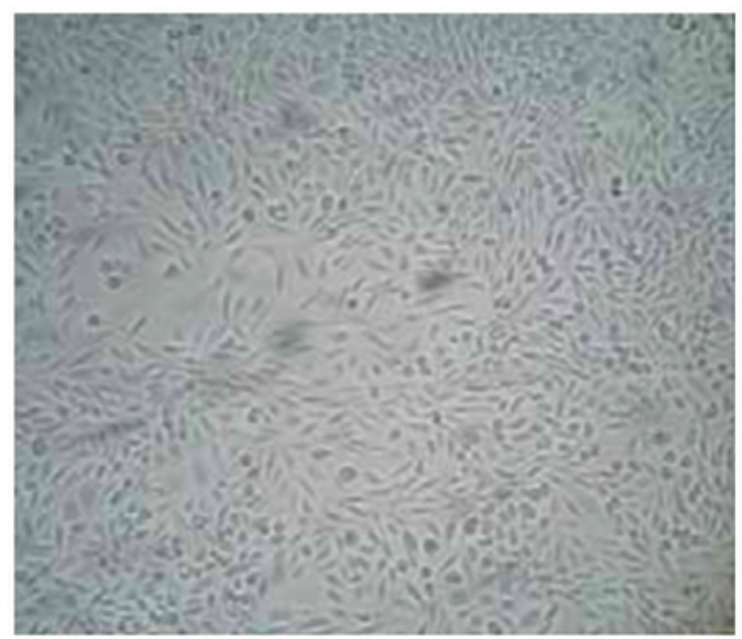

Figure 2. Caco-2 cell morphology without treatment.

the same concentration of 5 -aza-CdR and this process was repeated for 3 days. The RPMI-1640 medium containing the drug was then replaced by complete culture medium and incubated for 4-days. The same procedure as described above was
Table I. Inhibition of cell proliferation by 5 -aza-CdR in Caco-2 cells.

\begin{tabular}{lccccc}
\hline & \multicolumn{5}{c}{$\begin{array}{c}\text { Duration of exposure } \\
\text { of cells to 5-aza-CdR }\end{array}$} \\
\cline { 2 - 6 } $\begin{array}{l}\text { Concentration of } \\
\text { 5-aza-CdR, } \mu \text { mol/1 }\end{array}$ & $\begin{array}{c}\text { Day 1 } \\
(\%)\end{array}$ & $\begin{array}{c}\text { Day 2 } \\
(\%)\end{array}$ & $\begin{array}{c}\text { Day 3 } \\
(\%)\end{array}$ & $\begin{array}{c}\text { Day 4 } \\
(\%)\end{array}$ & $\begin{array}{c}\text { Day 5 } \\
(\%)\end{array}$ \\
\hline 0.4 & 97 & 94 & 92 & 90 & 89 \\
1.6 & 90 & 84 & 75 & 66 & 50 \\
6.4 & 80 & 74 & 68 & 56 & 40 \\
25.8 & 71 & 43 & 30 & 11 & 6 \\
102.4 & 48 & 40 & 9 & 7 & 5 \\
\hline
\end{tabular}

Concentration $(\mathrm{F}=44.079, \mathrm{p}<0.01)$, duration of exposure $(\mathrm{F}=12.250$, p $<0.01)$. 5-aza-CdR, 5-aza-2'-deoxycytidine.

Table II. Cell cycle and apoptosis in Caco-2 cells treated with 5-aza-CdR.

\begin{tabular}{lrrrr}
\hline & \multicolumn{4}{c}{ Cell cycle } \\
\cline { 2 - 5 } $\begin{array}{l}\text { Concentration of } \\
\text { 5-aza-CdR, } \mu \text { mol/1 }\end{array}$ & $\begin{array}{c}\text { Sub-G1 } \\
\text { phase }\end{array}$ & $\begin{array}{c}\text { G1 } \\
\text { phase }\end{array}$ & $\begin{array}{c}\mathrm{S} \\
\text { phase }\end{array}$ & $\begin{array}{c}\text { G2 } \\
\text { phase }\end{array}$ \\
\hline 0 & 1.78 & 56.21 & 22.01 & 15.27 \\
0.4 & 18.90 & 57.21 & 15.99 & 8.94 \\
1.6 & 37.81 & 45.31 & 9.98 & 7.54 \\
6.4 & 49.25 & 38.46 & 9.35 & 5.09 \\
25.6 & 38.21 & 44.67 & 6.72 & 3.75 \\
\hline
\end{tabular}

$\mathrm{t}=3.98, \mathrm{p}<0.05$ vs. $0 \mu \mathrm{mol} / 1.5$-aza-CdR, 5-aza-2'-deoxycytidine.

performed with the exception of 5-aza-CdR in cultured cells, which served as the control. During the incubation process, morphological changes in the cells treated with 5 -aza-CdR were observed using phase contrast microscope (Aipuda, Shanghai,China).

Growth curve using MTT assay. Caco- 2 cells were seeded in a 96-well plate at a density of $3 \times 10^{3}$ to a final volume of $200 \mu 1$. Cell culture medium containing a concentration of $5 \mathrm{~g} / \mathrm{l}$ of 5 -aza-CdR was changed regularly. A negative control (without 5 -aza-CdR) and a blank control (without cells) were included in each plate. MTT $(20 \mu \mathrm{l})$ was added to each well and incubated for $4 \mathrm{~h}$ at $37^{\circ} \mathrm{C}$. Following incubation, MTT was aspirated and the cells were rinsed twice with PBS. This step was followed by the addition of $150 \mu \mathrm{l}$ of DMSO and incubation for $15 \mathrm{~min}$. The optical density (OD) was determined at $570 \mathrm{~nm}$ in an ELISA reader (Perlong, Beijing, China). Cell proliferation was calculated according to the formula: Cell proliferation $=(\mathrm{OD}$ of treated - OD of blank)/(OD of the negative control-OD of the blank) x $100 \%$.

Cell cycle and apoptosis. The 5-aza-CdR-treated cells were collected and rinsed twice in PBS. The cells were adjusted to 


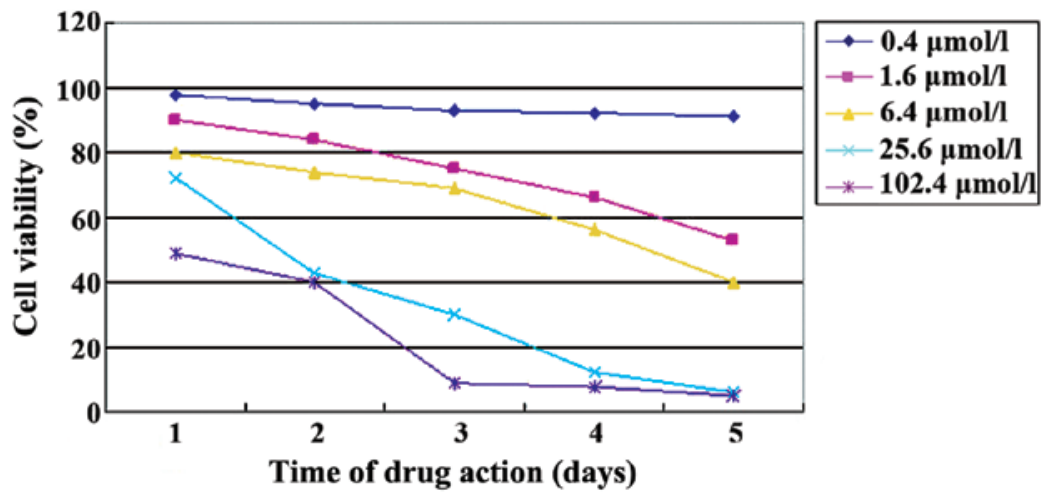

Figure 3. Cell growth curve at different concentrations of 5-aza-2'-deoxycytidine.

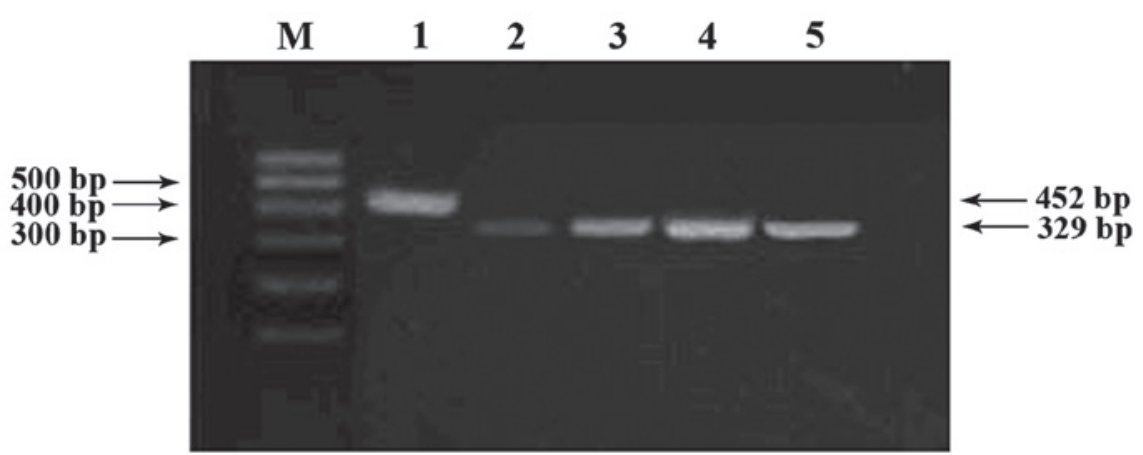

Figure 4. Ras association domain family 1A expression in 5-aza-2'-deoxycytidine (5-aza-CdR)-treated cells. Lane M, DNA molecular weight marker; lane 1, GAPDH; lane 2, $0.4 \mu \mathrm{mol} / 1$ (5-aza-CdR); lane 3, $1.6 \mu \mathrm{mol} / 1$; lane 4, $6.4 \mu \mathrm{mol} / 1$; and lane 5, $25.6 \mu \mathrm{mol} / 1$.

contain a cell density of $1 \times 10^{9} / 1$ in a flask. Subsequently, $5 \mathrm{ml}$ of ice cold hexanol $(700 \mathrm{ml} / \mathrm{l})$ was added to immobilize the cells for $24 \mathrm{~h}$. RNase A (Solarbio, Beijing, China) then was added (1 g/l). Propidium iodide (Leagene, Beijing, China) was added at a final concentration of $50 \mathrm{mg} / \mathrm{l}$ and incubated for $30 \mathrm{~min}$ at $37^{\circ} \mathrm{C}$. The cell cycle and apoptosis were determined in a flow cytometer (Potenov, Bejing, China).

Reverse transcription-polymerase chain reaction (RT-PCR). TRIzol $^{\circledR}$ reagent (Leagene, Beijing, China) was used to extract total RNA from the treated and untreated cells. The extracted total RNA was then reverse transcribed. Briefly, $2 \mu \mathrm{g}$ of total RNA was added to the pre-existing mixture of $1 \mu \mathrm{l} 10 \mathrm{X}$ reaction buffer (Leagene) with $\mathrm{MgCl}_{2}$ and $1 \mu \mathrm{l}$ DNase I. The non-specific inhibitor diethylpyrocarbonate (DEPC)-treated water was added to increase the volume to $10 \mu 1$, followed by incubation for $30 \mathrm{~min}$ at $37^{\circ} \mathrm{C}$. Subsequently, $1 \mu \mathrm{l}$ Oligo dT18 was added and mixed gently. A centrifugal separation step at $1,000 \mathrm{x} \mathrm{g}$ was performed after $5 \mathrm{~min}$ incubation at $70^{\circ} \mathrm{C}$. The tube was kept on ice. For reverse transcription, $5 \mu 15 \mathrm{X}$ Moloney Murine Leukemia Virus (M-MLV) buffer, $1.25 \mu$ l deoxyribonucleotide (dNTP) mixture, $1 \mu 1 \mathrm{M}-\mathrm{MLV}, 0.5 \mu 1 \mathrm{RNasin}$ and DEPC-treated water were added until a total volume of $25 \mu 1$ was achieved. Incubation was performed again for $15 \mathrm{~min}$ at $72^{\circ} \mathrm{C}$. RT-PCR was performed in a total volume of $25 \mu \mathrm{l}$ and the constituents used were: $2.5 \mu 1$ 10X PCR buffer, $0.5 \mu 1$ dNTP mixture, $0.625 \mu 1 \mathrm{MBI}$ TaqDNA polymerase, $1 \mu \mathrm{l}$ primer $1(10 \mu \mathrm{mol} / \mathrm{l}), 1 \mu \mathrm{l}$ primer $2(10 \mu \mathrm{mol} / \mathrm{l}), 1.5 \mu \mathrm{l} \mathrm{MgCl}_{2}$, $1 \mu \mathrm{l} \mathrm{cDNA}$ and sterile distilled water (final volume of $25 \mu \mathrm{l}$ ).
RASSF1A-specific primers were used to achieve PCR amplification. GAPDH was selected as a reference owing to its stable expression (8). RASSF1A primers were selected from a previously published study (9). The primers used were: forward: 5'-GGCGTCGTGCGCAAAGGCC-3' and reverse: 5'-GGGTGGCTTCTTGCTGGAGGG-3'. The primer sequences for GAPDH were: forward 5'-ACCACA GTCCATGCCATCAC-3' and reverse 5'-TCCACCACCCTG TTGCTGTA-3'. The PCR amplification step consisted of initial denaturation at $95^{\circ} \mathrm{C}$ for $5 \mathrm{~min}, 35$ cycles of denaturation at $94^{\circ} \mathrm{C}$ for $30 \mathrm{sec}$, annealing at $56^{\circ} \mathrm{C}$ for $30 \mathrm{sec}$, extension at $72^{\circ} \mathrm{C}$ for $60 \mathrm{sec}$ and a final extension at $72^{\circ} \mathrm{C}$ for $5 \mathrm{~min}$. Thus the PCR amplicons were visualized on $2 \%$ agarose gel (Novelab, Shanghai, China).

Statistical analysis. Experimental data were processed using SPSS software (IBM, Armonk, NY, USA) and F-test and T-tests were performed.

\section{Results}

Morphology and cell proliferation. Morphological changes in Caco-2 cells prior to and following 5-aza-CdR treatment were observed under an inverted microscope (Dygx, Shanghai, China). The treated cells decreased in volume and density, and died (Fig. 1A and B). No such abnormalities were observed in the untreated cells (Fig. 2). The MTT assay showed that 5-aza-CdR inhibited Caco-2 cell proliferation. The number of cells in which proliferation was inhibited by 5 -aza-CdR 
was elevated with an increasing concentration of 5-aza-CdR $(\mathrm{F}=44.079, \mathrm{p}<0.01)$ and exposure time $(\mathrm{F}=12.250, \mathrm{p}<0.01$, Table I, Fig. 3) was observed.

Cell cycle and apoptosis. 5-aza-CdR treatment induced cell cycle arrest and caused accumulation of cells in the G0/G1 phase. Accumulation of the G0/G1 phase cells was enhanced with an increasing dose of 5-aza-CdR (Table II). Flow cytometry showed that the percentage of apoptotic cells in the absence of 5 -aza-CdR was $1.78 \%$ while the same increased to $49.25 \%$ when they were treated with $6.4 \mu \mathrm{mol} / \mathrm{l}$ of 5-aza-CdR, and this difference was statistically significant $(\mathrm{t}=3.98, \mathrm{p}<0.05$ vs. $0 \mu \mathrm{mol} / \mathrm{l}$; Table II). When 5 -aza-CdR concentration reached $102.4 \mu \mathrm{mol} / 1$, cell necrosis instead of cell apoptosis occurred.

RT-PCR analysis of the RASSF1A gene. Caco-2 cells originally lacking $R A S S F 1 A$ gene expression were treated with 5-aza-CdR. Re-expressed RASSF1A mRNA was dependent on the concentration of 5-aza-CdR as observed in the $2 \%$ agarose gel after RT-PCR analysis (Fig. 4).

\section{Discussion}

5-aza-CdR has been identified to be effective in treating recurrent, intractable, acute and chronic myelogenous leukaemia $(10,11)$. However, its effectiveness against solid tumors remains unclear. Hypomethylation and hypermethylation have been observed in various types of cancer $(12,13)$. Hypomethylation can contribute to genomic instability, activation of oncogenes, or loss of imprinting. Gene-specific promoter hypermethylation in tumor suppressor genes cause silencing of tumor suppressors, which can contribute to many of the hallmarks of cancer such as evading apoptosis, insensitivity to antigrowth signals, sustained angiogenesis, limitless replicative potential and tissue invasion and metastasis. Previous findings have shown that aberrant gene methylation in cancer renders them resistant to chemotherapeutics via inhibition of apoptosis. Since methylation involves changes in gene regulation but not the DNA sequence, the change is reversible. The silenced tumor suppressor genes can be re-expressed when hypermethylation in their promoter region is removed that may ultimately repress tumor growth (14-19).

In the current study, a concentration- and time-dependent inhibition of proliferation of Caco-2 cells was identified following treatment with different concentrations of 5-aza-CdR. The percentage of Caco- 2 cells in the G0/G1 phase was enhanced with an increasing the dose of 5-aza-CdR, thereby increasing the cells that undergo apoptosis. The morphological changes including decreased cell volume and density and cell death were observed at low doses of 5-aza-CdR, whereas cell disruption and necrosis were observed at higher doses of 5-aza-CdR. The changes were similar to the cytotoxic effects attributed to chemotherapeutic drugs where apoptosis occurs at lower doses and necrosis at higher doses. Additionally, the RASSFIA gene, which is silenced by hypermethylation in Caco-2 cells, was reactivated by the 5 -aza-CdR treatment. The mRNA expression of RASSFIA gene was identified even after five successive generations. The reason for this might be the demethylating effect of 5-aza-CdR. The re-expression therefore contributed to the tumor suppressive function in Caco-2 cells. It is also possible that the cytotoxicity of 5-aza-CdR leads to an anticancer effect. However, 5-aza-CdR does not lead to an anticancer effect by exerting cytotoxity on cancer cells. Studies (20-22) have been carried out in which Ara-C, an equally cytotoxic drug as 5-aza-CdR, was used to determine whether the anticancer effect attributed by 5 -aza-CdR was due to cytotoxicity in bladder cancer cells. Ara-C did not possess a demethylating capability. The two drugs inhibited cell proliferation although the inhibitory effect of Ara-C was not transmitted, demonstrating that inhibitory effect of 5-Aza-CdR is not derived from cytotoxicity.

It has been reported that Ras-GTPase is a member of the superfamily of molecular switches regulating proliferation and apoptosis (23-27). It performs different functions dependent on the signal molecule. Ras-GTPase interacts with a series of different downstream effector molecules to promote cell growth and differentiation, inducing cell dormancy, terminal differentiation and apoptosis in order to suppress cell growth.

RASSF1A gene methylation was found to be present in various types of cancer. Previous studies $(28,29)$ using methylation-specific PCR examined colorectal cancer and identified that RASSFIA CpG-island in the neoplastic foci region methylated more frequently than the periphery of the neoplastic foci. Kuroki et al $(30,31)$ and other investigators (32-34) using methylation-specific PCR analyzed esophageal carcinoma, gastric carcinoma and bladder cancer and observed that, RASSF1A was hypermethylated and the degree of methylation correlated closely with the clinical stages of patients. RASSF1A gene expression was silenced by hypermethylation of the CPG island in the promoter region of a wide range of tumors. Müller et al (35) analyzed the aberrant DNA methylation of RASSFIA in breast cancer and found that patients with aberrant RASSF1A methylation had a poorer prognosis.

In conclusion, the current findings suggest that RASSF1A can result in an antitumor effect when Caco-2 cells are treated with 5-aza-CdR. The demethylating agent 5-aza-CdR embraces good prospects in antitumor therapy, given the universality of regional hypermethylation in tumor cells.

\section{References}

1. Fandy TE: Development of DNA methyltransferase inhibitors for the treatment of neoplastic diseases. Curr Med Chem 16: 2075-2085, 2009.

2. Zhang $\mathrm{Y}, \mathrm{Ng} \mathrm{HH}$, Erdjument-Bromage $\mathrm{H}$, Tempst P, Bird A and Reinberg D: Analysis of the NuRD subunits reveals a histone deacetylase core complex and a connection with DNA methylation. Genes Dev 13: 1924-1935, 1999.

3. Prokhortchouk A, Hendrich B, Jørgensen H, Ruzov A, Wilm M, Georgiev G, Bird A and Prokhortchouk E: The p120 catenin partner Kaiso is a DNA methylation-dependent transcriptional repressor. Genes Dev 15: 1613-1618, 2001.

4. Bird AP: The relationship of DNA methylation to cancer. Cancer Surv 28: 87-101, 1996.

5. Bird A: DNA methylation de novo. Science 286: 2287-2288, 1999.

6. Dammann R, Li C, Yoon JH, Chin PL, Bates S and Pfeifer GP: Epigenetic inactivation of a RAS association domain family protein from the lung tumour suppressor locus 3 p21.3. Nat Genet 25: 315-319, 2000. 
7. Dammann R, Takahashi T and Pfeifer GP: The CpG island of the novel tumor suppressor gene RASSF1A is intensely methylated in primary small cell lung carcinomas. Oncogene 20: 3563-3567, 2001.

8. Bartling B, Hoffmann J, Holtz J, Schulz R, Heusch G and Darmer D: Quantification of cardioprotective gene expression in porcine short-term hibernating myocardium. J Mol Cell Cardiol 31: 147-158, 1999.

9. Burbee DG, Forgacs E, Zöchbauer-Müller S, Shivakumar L, Fong K, Gao B, Randle D, Kondo M, Virmani A, Bader S, et al: Epigenetic inactivation of RASSF1A in lung and breast cancers and malignant phenotype suppression. J Natl Cancer Inst 93 691-699, 2001.

10. Piekarz RL andBates SE: Epigenetic modifiers: basic understanding and clinical development. Clin Cancer Res 15: 3918-3926, 2009.

11. Wijermans P, Lubbert M, Verhoef G, Bosly A, Ravoet $C$ and Andre Mand Ferrant A: Low-dose 5-Aza-2'-deoxycytidine, a DNA hypomethylation agent for the treatment of high-risk myelodyspastic syndrome: a multicenter phase II study in elderly patients. J Clin Oncol 18: 956-960, 2000.

12. Xhu XJ and Dai DQ: Epigenetics and gastrointestinal cancer Chin J Digest 14: 3215-3256, 2006.

13. Tomita H, Hirata A,Yamada Y, Hata K, Oyama T, Mori H, Yamashita S, Ushijima T and Hara A: Suppressive effect of global DNA hypomethylation on gastrc carcinogenesis. Carcinogenesis 31: 1627-1633, 2010

14. Zöchbauer-Müller S, Fong KM, Virmani AK, Geradts J, Gazdar AF and Minna JD: Aberrant promoter methylation of multiple genes in non-small cell lung cancers. Cancer Res 61 : 249-255, 2001

15. Daskalakis M, Nguyen TT, Nguyen C, Guldberg P, Köhler G, Wijermans P, Jones PA and Lübbert M: Demethylation of a hypermethylated P15/INK4B gene in patients with myelodysplastic syndrome by 5-Aza-2'-deoxycytidine (decitabine) treatment. Blood 100: 2957-2964, 2002.

16. Bae SI, Lee HS, Kim SH and Kim WH: Inactivation of O6-methylguanine-DNA methyltransferase by promoter $\mathrm{CpG}$ island hypermethylation in gastric cancers. Br J Cancer 86 : 1888-1892, 2002.

17. Esteller M, Corn PG, Baylin SB and Herman JG: A gene hypermethylation profile of human cancer. Cancer Res 61: 3225-3229, 2001 .

18. Lübbert M, Tobler A and Daskalakis M: Cytosine demethylation of the proteinase-3/myeloblastin primary granule protease gene during phagocyte development. Leukemia 13: 1420-1427, 1999.

19. Kim SH, Bae SI, Lee HS and Kim WH: Alteration of $\mathrm{O}^{6}$-methylguanine-DNA methyltransferase in colorectal neoplasms in sporadic and familial adenomatous polyposis patients. Mol Carcinog 37: 32-38, 2003.

20. Bender CM, Pao MM and Jones PA: Inhibition of DNA methylation by 5-aza-2'-deoxycytidine suppresses the growth of human tumor cell lines. Cancer Res 58: 95-101, 1998.

21. Gonzalgo ML, Hayashida T, Bender CM, Pao MM, Tsai YC, Gonzales FA, Nguyen HD, Nguyen TT and Jones PA: The role of DNA methylation in expression of the p19/p16 locus in human bladder cancer cell lines. Cancer Res 58: 1245-1252, 1998.
22. Xiong Z, Wu AH, Bender CM, Tsao JL, Blake C, Shibata D, Jones PA, Yu MC, Ross RK and Laird PW: Mismatch repair deficiency and $\mathrm{CpG}$ island hypermethylation in sporadic colon adenocarcinomas. Cancer Epidemiol Biomarkers Prev 10: 799-803, 2001

23. Dammann R, Schagdarsurengin U, Strunnikova M, Rastetter M, Seidel C, Liu L, Tommasi S and Pfeifer GP: Epigenetic inactivation of the Ras-association domain family 1 (RASSF1A) gene and its function in human carcinogenesis. Histol Histopathol 18 : 665-677, 2003

24. Liu L, Tommasi S, Lee DH, Dammann R and Pfeifer GP: Control of microtubule stability by the RASSF1A tumor suppressor. Oncogene 22: 8125-8136, 2003.

25. Strunnikova M, Schagdarsurengin U, Kehlen A, Garbe JC, Stampfer MR and Dammann R: Chromatin inactivation precedes de novo DNA methylation during the progressive epigenetic silencing of the RASSF1A promoter. Mol Cell Biol 25: 3923-3933, 2005.

26. Chow LS, Lo KW, Kwong J, To KF, Tsang KS, Lam CW, Dammann R and Huang DP: RASSF1A is a target tumor suppressor from $3 \mathrm{p} 21.3$ in nasopharyngeal carcinoma. Int J Cancer 109: 839-847, 2004.

27. Tommasi S, Dammann R, Zhang Z, Wang Y, Liu L, Tsark WM, Wilczynski SP, Li J, You M and Pfeifer GP: Tumor susceptibility of Rassfla knockout mice. Cancer Res 65: 92-98, 2005.

28. Lee s, Hwang KS, Lee HJ, Kim JS and Kang GH: Aberrant $\mathrm{CpG}$ island hypermethylation of multiple genes in colorectal neoplasia. Lab Invest 87: 884-893, 2004.

29. Kang GH, Lee HJ, Hwang KS, Lee S, Kim JH and Kim JS: Aberrant $\mathrm{CpG}$ island hypermethylation of chronic gastritis, in relation to aging, gender, intestinal metaplasia, and chronic inflammation. Am J Pathol 163: 1551-1556, 2003.

30. Kuroki T, Trapasso F, Yendamuri S, Matsuyama A, Alder H, Mori M and Croce CM: Allele loss and promoter hypermethylation of VHL, RAR-beta, RASSF1A, and FHIT tumor suppressor genes on chromosome $3 p$ in esophageal squamous cell carcinoma. Cancer Res 63: 3724-3728, 2003.

31. Kuroki T, Trapasso F, Yendamuri S, Matsuyama A, Alder H, Mori $\mathrm{M}$ and Croce CM: Promoter hypermethylation of RASSF1A in esophageal squamous cell carcinoma. Clin Cancer Res 9: 1441-1445, 2003.

32. Byun DS, Lee MG, Chae KS, Ryu BG and Chi SG: Frequent epigenetic inactivation of RASSF1A by aberrant promoter hypermethylation in human gastric adenocarcinoma. Cancer Res 61: 7034-7038, 2001.

33. Lee MG, Kim HY, Byun DS, Lee SJ, Lee CH, Kim JI, Chang SG and Chi SG: Frequent epigenetic inactivation of RASSF1A in human bladder carcinoma. Cancer Res 61: 6688-6692, 2001.

34. Chan MW, Chan LW, Tang NL, Lo KW, Tong JH, Chan AW, Cheung HY, Wong WS, Chan PS, Lai FM, et al: Frequent hypermethylation of promoter region of RASSF1A in tumor tissues and voided urine of urinary bladder cancer patients. Int $J$ Cancer 104: 611-616, 2003.

35. Müller HM, Widschwendter A, Fiegl H, Ivarsson L, Goebel G, Perkmann E, Marth C and Widschwendter M: DNA methylation in serum of breast cancer patients: an independent prognostic marker. Cancer Res 63: 7641-7645, 2003. 